\title{
Musical world of Mikhail Bakhtin as objectivation of the idea of cultural synthesis
}

\author{
Natalia Voronina $^{1}$, Svetlana Dubrovskaya ${ }^{1}$, Irina Klyueva $^{1, *}$, and Andrey Sychev ${ }^{1}$ \\ ${ }^{1}$ Mordovia State University, 430005, Saransk, Russia
}

\begin{abstract}
Researchers repeatedly noted that M.M. Bakhtin's works are characterized by integration of musical culture into theoretical discourse, which is expressed in his appeal to the conceptual sphere of musical art and use of musical terminology as an instrument of literary, aesthetic, and cultural analysis. However, when examining Bakhtin's connection with music, researchers, as a rule, discuss "music in general", without specifying which music Bakhtin used to listen. The paper discusses the phenomenon of "the musical world of Bakhtin", including his music experience, personal and creative contacts with musicians. The authors find out musical sources of Bakhtin's creative intuitions. Based on the study of Bakhtin's collection of gramophone records (now located in the M. M. Bakhtin Center of the Mordovia State University), published and oral memories of people personally communicating with Bakhtin, and other sources, his individual musical preferences are identified, and the circle of his favorite composers and performers is determined. It is emphasized that the phenomenon of the "Bakhtin's musical world" is a "marker" of his commitment to the tendency of interaction and synthesis of arts, intermediality, and the objectification of the idea of cultural synthesis, which was one of the prevailing philosophical and cultural intuitions of Russian symbolism.
\end{abstract}

\section{Introduction}

M. M. Bakhtin used to emphasize that in the initial part of his creative activity he "belonged to the circle of symbolists" with all his "ties and sympathies" [1]. In cultural studying of Russian symbolism the art terms have become universal language which was necessary for making conceptual world models. The idea of cultural synthesis as the interaction and interpenetration of cultural spheres, one of the manifestations of which is the interaction of art forms, intermediality, was relevant. We constantly find images and terms from different art creativity spheres in Bakhtin's works ("painting" / "picturesque", "sculpture" / "sculptural", "plastically-picturesque", "dance" ("playska"), "theater" / "theatrical", etc.) - not only when the scientist makes parallels between literature and other forms of art, but also in relation to literature itself, as well as culture in general.

It is a characteristic feature of Bakhtin to appeal to the conceptual sphere of musical art

\footnotetext{
*Corresponding author: klyueva_irina@mail.ru
} 
("music" / "musical", "sound" ("sound recording", "sounding", "sound instrumentation", "sound symbolism"), "voice" ("double voice", "multiple voices"), “counterpoint", "polyphony" / "polyphonic", and "homophone" / "homophonic", etc.), using terms common to music and literature ("tone", "rhythm", "intonation" / "intonational", "chorus" / "choral", etc.). In the records of lectures delivered by the scholar at the Mordovia University, the names of composers Berlioz, Beethoven, Mozart, and several times Wagner are mentioned [2].

The researchers addressed to some aspects of such broad topic as "Bakhtin and art". His work was studied in the relation to theater [3], visual culture [4], fine art in general [5], and its specific types [6].

Such part of the above named topic as "Bakhtin and music" has been repeatedly analyzed. Thus, N. I. Voronina considered the issue of friendly relations between the thinker and the pianist M. V. Yudina [7], R. A. Telcharova regarded the problem of musical thinking [8], I. V. Klyueva - the musical component of his work in the context of the "choral utopia" of the Silver age in Russia [9].

A. I. Kalygin in his monograph on Bakhtin's early work paid considerable attention to musical terminology [10]. E. Gritten outlined the development of the "musicality" problem as "generating, cultivating and exhibiting wisdom", highlighting the three main concepts of Bakhtin's aesthetics related to music: "emotional-volitional tone" ("intonation"), "rhythm", "aesthetic love" [11]. S. Fast considered Bakhtin's concepts of speech genres, dialogue and polyphony in comparison with the discourse of musical theory of the Late Middle Ages [12].

Dealing with Bakhtin's connection to music, the researchers dwell on "music in general" without specifying the kind of music inspiring for Bakhtin. The article written by T. N. Levaya, comparing Bakhtin's ideas with the work of D. D. Shostakovich can be treated as an exception [13].

In this article we think over "Bakhtin's music world" as phenomenon including into itself his way of listening and feeling music, his personal and creative contacts with musicians and consequently, "musical" aspects of his work. Our aim is to find out what kind of music (composers, performers) Bakhtin listened to and appreciated and how it was reflected in his work.

Published memoire sources, phonograph records belonging to Bakhtin, as well as the interviews data of 1990-2010-ies conducted by the members of the research group interviewing residents of Saransk, communicating with Bakhtin in the 1950s and 1960s served as the material for the analysis (the interviews of Bakhtin's neighbours - lectures of the University A. M. and T. A. Shepelevs, P. S. Rabinovich, professor (in the 1950s employee) of the University L. G. Filatov, professor of the University (in the 1950s student) N. F. Mokshin, graduate of the University N. N. Kuzovenkova, former graduate student of Bakhtin, later associate professor A.V. Dialectova, engineer (in the 1950s college graduate L. N. Sobolevskaya).

\section{Bakhtin's musical impressions as a source of his creative intuitions}

Talking with V. D. Duvakin Bakhtin mentioned: "I... am not a musician... not a professional... not a specialist in music...", while to the communicator's response: "You're a man of music" Bakhtin said: "I'm musical... I am under music... and I understand it, of course", he emphasized: "Philosophy, mythology, religion, and music are the most related in the world... Music... is both philosophical and religious in its very nature" [14].

Bakhtin shared with Duvakin his musical impressions, starting from his youth, such as F. I. Chaliapin singing in Vilna (indeed, on September 4 (17), 1910 Chaliapin gave a 
concert in this city [15], recalled the Odessa Opera Theater, where outstanding singers of Russia and Europe performed [16].

Bakhtin's life in Petrograd (1916-1918) was connected not only with literary, but also with musical impressions. During this period, he met with the future scientist-petrographer B. V. Zalessky, an amateur pianist and music connoisseur who would become his closest friend. Later Zalessky married an outstanding pianist M. K. Yushkova, with whom he (and probably Bakhtin) was already in close contact during this period.

Here (or somewhat later - in Nevel in 1919) Bakhtin met with V. N. Voloshinov. A future linguist, philosopher, musicologist, Voloshinov during this period positioned himself as a poet, pianist and composer. He was strongly influenced by A. N. Scriabin, studied with his students, but was forced to part with the dream of a professional career as a musician due to illness.

The pianist was Voloshinov's closest friend, a student of the Polytechnic Institute, later an engineer V. Z. Rugevich, with whom Bakhtin first met in Nevel. Here Rugevich met his future wife, A. S. Rebezova, who would also enter the close circle of Bakhtin later. Being a medical doctor by profession, she was connected with music "vitally" - as she was the granddaughter of the composer A. G. Rubinstein.

Rugevich (together with Voloshinov) lived in the vicinity of Nevel - in the estate Otradnoye, located near the farm Zatishie, where their mutual friend B. M. Zubakin organized a "commune-church", the members of which was also the painter R. I. Buynitsky with his wife A. G. Kazakovskaya, a singer, a soloist of the Mariinsky theater (they lived in the neighbouring estate).

In the estate of Buynitsky there was harmonium he presented to his wife, which "disappeared without a trace" in the 1920s, when Buynitsky's property was confiscated [17]. Zubakin recalled: "We lived with ... singing, music (Voloshinov was also a composer, Buynitsky and Rugevich were excellent pianists, Buynitskaya-Krunek was a singer)..." [18].

In Nevel, Voloshinov was teaching literature, he also conducted piano classes at a music school, held the position of the head of extracurricular education, and later the music section head of the public education district department.

The intellectual interests of one more Bakhtin circle member - M. I. Kagan were also connected with music during this period. On the Day of Art (September 13, 1919) before the Symphony concert in the People's house, he read a report "Music and lyrics" [19].

In Nevel Bakhtin got acquainted and set up lifelong friendship with Yudina. During this period, the pianist was particularly interested in two composers - Bach and Beethoven. It was their music that spiritually and philosophically brought her closer to Bakhtin and Voloshinov. It is not by chance that in A. F. Losev's "strange" novel "The WomanThinker", written in 1933-1934, where Yudina (pianist Radina) and representatives of Bakhtin Circle were parodicaly depicted; Bakhtin (Novikov) was nicknamed "Bachianchik", and Voloshinov (Ignatiev) - "Beethovenchik" [20].

Bakhtin emphasized that Yudina "“...loved and played strong music: Bach, List, Beethoven and some contemporary musicians [21]. Yudina measured music with a tragic, Beethoven measure, considering the purpose of art "to discover for mankind the truths of divine revelation but not at all to give pleasure" [22]. Bakhtin shared such understanding of music: "Life ... includes death as a necessary element... All poetry as such, as well as all music... all arts... were always linked... with memory about ancestors, about deceased, with grave... and lamentation..." [23].

"Strong music", which Yudina and Bakhtin preferred, "was on the border of musical and somewhat higher, mythological or religious..." [24]. The thinker deliberately stressed that the main feature of Yudina "as a person and as a cultural figure" was the thing that she "could not place herself into... some specialty, she could not limit herself to only music... In 
music, she chose everything that was on the border of music and other arts... She chose music when it was close to either ... poetic revelation or religious revelation..." [25].

Bakhtin's close connection with music continued in Vitebsk, where he and L. V. Pumpyansky lectured on the philosophy of music. Voloshinov (who lived in the same house with Bakhtin) taught at the Conservatory, worked as the head of the music Department of the (Provincial Department of Political Education), led classes in a music studio, organized a chamber orchestra. In 1920, he had been studying piano at the Conservatory for some period of time, published musicological articles about Beethoven and M. P. Mussorgsky in the journal "Iskusstvo" ("Art").

In Vitebsk Bakhtin got acquainted with I. I. Sollertinsky. Contacts with representatives of the "Circle" contributed to the fact that music became the center of interests and determined the choice of profession of an outstanding musicologist. Sollertinsky's statements about Beethoven are worth mentioning as definitions of Beethoven's symphonism as "dramatic", "poly-personal", "multy-personal", coming out "not from the monologue, but from the dialogic principle, from the principle of plurality of consciousnesses, plurality of opposing ideas and wills, from dialogical variety contrasted to the monologue integrity - that is the principle of "other self"” [26].

The scientist biography Leningrad period (1924-1930) was also closely connected with music. The first years he and his wife lived at the Rugeviches'. Bakhtin remembered the evenings in the flat where gathered people "having ties to literature, music and other kinds of art" [27].

The daughters of Archpriest F. K. Andreev, with whom Bakhtin and his friends communicated then - M. F. Andreeva and A. F. Mozhanskaya, recalled that the Rugeviches had a harmonium in addition to the piano (we assume that it was just the one that "had disappeared", though, in fact, it was rescued from Buynitsky's estate before confiscation). Yudina played the piano, V. Z. Rugevich played the harmonium, the hostess's friend A. G. Koltovskaya came with the organola, a beautiful contralto E. A. Tagatz - future wife of another Bakhtin's close friend, scientific-biologist I. I. Kanaev, was singing [28]. Having grown up Andreev sisters also visited "musical" apartment of the Rugeviches: "the two rooms were overcrowded... We were fascinated by the harmonium played by Vladimir Zinovievich. We listened to beautiful trumpet sounds and still hear them in our ears" [29].

In Leningrad, Bakhtin often visited Yudina's apartment, where representatives of the "Circle" spent nights listening to her play: "Oh, how she played then, on these nights, for a narrow circle of her friends... she had never played like that any more" [30].

It is known that the violin was played by A. Blok's closest friend E. P. Ivanov, with whom Bakhtin also closely communicated in Leningrad.

Bakhtin informed Duvakin about his acquaintance with literary scholar S. A. Andrianov, he recalled his wife, singer Zoya Lody, "an exquisite camera singer... who sang rare ... folk pieces... She deliberately studied Italian songs in Italy..." [31].

V. M. Khodasevich wrote that in 1925, in Italy, where Lody met Gorky, the singer "dug up in the archives and learned extraordinary beautiful Italian songs and romances of the Middle Ages and the Renaissance, which she first performed" [32]. A. I. Tsvetaeva, who was connected with Bakhtin by a common friendship with Voloshinov and the Kagan family, also recalled the "heavenly charm" of Lody's singing, "the refinement in conveying melodies merged with the content of the song" [33].

Russian romances, French songs by J.-B. Weckerlin, works of European composers (Bach, Beethoven, Mozart, Brahms, Schubert, Schumann, etc.) and Russian classics (Glinka, Mussorgsky, Tchaikovsky, etc.), as well as folk songs were included in the repertoire of Lody.

\section{Music in the Saransk period of M. M. Bakhtin's life}


In the winter of 1951 Yudina came to Bakhtin in Saransk.

B. S. Uritskaya recalled her concert in the Mordovia Republican Radio Studio, where there was the best piano in the city: “... Maria Veniaminovna said that she wanted to play for Mikhail Mikhailovich, that she was ready to "give a small concert" ... she had been playing the whole evening... There was a very special atmosphere of unexpected entering the sphere of real art... But it seemed that Yudina had played especially for Bakhtin, who had not heard her for a long time..." [34]. P. S. Rabinovich recalled that all the neighbors and good friends of the Bakhtins came to the concert: "the impression was unforgettable. Bakhtin was a great lover of music".

A. M. Shepeleva also stressed that the scientist and his wife loved music, they perceived it very emotionally. Bakhtin listened to serious classical music only, he didn't "accept" stage music, even all the favorite singers at the time like K. Shulzhenko and L. Ruslanova (singer of folk songs on the stage): "He just winced: "It's transient, it will all pass away" he said to L. G. Filatov about pop music. N. F. Mokshin states: "Bakhtin was shocked by stage music. He was brought up on the classics".

The writer V. N. Barmichev, who communicated with Bakhtin in Saransk in the 1960s, claimed that he "did not like either Russian music or painting. As Bakhtin said: "I'm not a fan of Russian art and Russian music". He loved European music more" [35].

In 1953-1963 N. N. Kuzovenkova closely communicated with Bakhtin and his wife and repeatedly spoke to him about her favorite composer Beethoven. He recommended her to read G. Berlioz's memoirs, R. Rolland's "Life of Beethoven", T. Mann's novel "Doctor Faustus". "He was very fond of Bach", - she emphasized. According to A. V. Dialectova, of all the composers Wagner was the closest to Bakhtin.

In 1959-1960 engineer L. N. Sobolevskaya attended classes in the city University of culture, Bakhtin was the best lecturer there, who lectured on outstanding composers and artists. She remembered his lectures on the work of Bach and Beethoven, which she called "a magical act": "Bakhtin spoke, his assistant turned on the music... We all felt something magical...".

While comparing Bakhtin with Shostakovich's work T. N. Levaya, substantiates his logic by the relative synchronicity of biographical milestones and general intellectual atmosphere of Petrograd-Leningrad of the 1920s, emphasizing that outwardly these names "seem to be unrelated", the musician and the scientist "did not biographically intersect" [36].

There is no information about Bakhtin's "direct contacts" with Shostakovich, though we are aware of "indirect communication", through mutual friends - Sollertinsky and Yudina. However, the fact of personal acquaintance should not be excluded. Talking with Duvakin, Bakhtin mentioned Shostakovich's teacher, L. V. Nikolaev, and emphasized that he knew many of his students [37]. T. A. Shepeleva claims that Bakhtin's wife repeatedly spoke with her about Shostakovich, calling him "Mitenka".

In 1959 Bakhtin co-authored with his colleague L. G. Vasilyev wrote a review of the performance of the State drama theatre of the Mordovian Republic "Na rassvete" ("At dawn") based on the play by G. Y. Merkushkin (that time the rector of the Mordovia State University). The drama is dedicated to the events of the civil war in Russia (the action takes place in 1919). The disadvantage of the production pointed out by the authors was "not quite satisfying musical arrangement", it was stressed that for "strengthening the historical flavor of the performance", its authors, in particular, would "use the music of D. Shostakovich" [38].

Bakhtin's musical preferences can also be judged by the phonograph records he listened to in the last years of his life in Moscow. Then a player was bought for him, it was observed in 1973 in his apartment by musicologist A. M. Kuznetsov, who presented him at his 
request phonographs records of d-minor Concerto for piano with orchestra by Mozart (soloist M. W. Yudina) and Symphony No 15 by Shostakovich [39].

Bakhtin received phonograph records as a gift from his new friends - young Moscow scientists and from his visitors.

Today the player and part of the records are included in the memorial exposition of the M. M. Bakhtin Center at Mordovia State University. Among them are recordings of music by Bach ("St John Passion", part II), Beethoven (Overture "Leonora" No. 3, Op. 72A), Brahms (Three pieces from Op. 118), Wagner (opera "Lohengrin", overtures to the operas "Meistesingers" and "Tannhäuser", "Siegfried's Journey on the Rhine" and Mourning March from the opera "The Death of the Gods"), Mozart ("Requiem"), R. Schumann ("Colored Leaves", Op. 99), H. Schütz ("Small concerts of church music").

\section{Conclusion}

The formation and development of Bakhtin as a thinker was going "with music" (in a musical environment) and to a large extent under its influence. Music as an art was in the field of intellectual and spiritual interests of all the representatives of the "Circle", Bakhtin's close friends, many of whom had musical education or/and were associated with music "vitally" (having close relatives, family members - musicians).

Bakhtin did not accept light, pop music absolutely, he was critical even of the best such samples. He was not a "music lover", his musical taste was strict and selective, preferences were determined by the high criteria of "Great time of culture", by those areas where music was connected with philosophy and religion, correlated with the existentials of Life, Death and Immortality.

All the composers Bakhtin listened to, including the most beloved (Bach, Beethoven, Wagner) are outstanding representatives of musical polyphonies, so the idea of polyphonism in relation to verbal art arose not by chance - it crystallized from the common interests of the "Circle".

The theme "Bakhtin and music" is multidimensional and requires further study. Special attention should be paid to the section "Bakhtin and Shostakovich", for instance to composing of the opera "The Nose" (1927-1929) and the emergence of "nosological" problems in Bakhtin's work. The problem of Bakhtin's use of musical terminology as a tool of literary, philosophical, aesthetic and cultural analysis needs further research and specification.

\section{References}

1. M. M. Bakhtin, Conversations with V. D. Duvakin (Consent Publishing house, Moscow, 2002). [in Rus.].

2. I. V. Klyueva, L. M. Lisunova, M. M. Bakhtin - thinker, teacher, person (Red October Publishing house, Saransk, 2010). [in Rus.].

3. I. V. Klyueva, Theater in M. M. Bakhtin's life and work, M. M. Bakhtin readings, 2, 294-300. (Publishing house of the Oryol State Television and Radio Broadcasting Company, Oryol, 1997). [in Rus.].

4. B. Brait, Looking and Reading: Verbal-Visuality from a Dialogical Perspective, Bakhtiniana, 8 (2), 42-64 (2013). (in Portugal).

5. D. J. Haynes, Bakhtin and the visual arts (Cambridge a. New York, Cambridge Univ. Publ., 1995).

6. I. V. Klyueva, "Sculptural topic" in M. M Bakhtin's creative consciousness, 
Historical, Philosophical, Political and Law Sciences, Culturology and Study of Art. Issues of Theory and Practice, 5-1 (43), 103-105 (2014). [in Rus.].

7. N. I. Voronina, M. M. Bakhtin and M. V. Yudina, The origins and horizons of friendship. (On the Problem of Mutual Influence of Philosophy and Music)], M. M. Bakhtin: Aesthetic Heritage and Modernity, II, 179-188 (Publishing House of Mordovia State University, Saransk, 1992). [in Rus.].

8. R. A. Telcharova, Musicality of thinking as a technique of methodological plastics, M. M. Bakhtin: Aesthetic Heritage and Modernity, II, 226-233 (Publishing House of Mordovia State University Saransk, 1992). [in Rus.].

9. I. V. Klyueva, "Choral Utopia" of the Silver Age and M. M. Bakhtin's work Bakhtin and time: the IVth Bakhtin scientific readings, 102-104 (Publishing House of Mordovia State University, Saransk, 1998). [in Rus.].

10. A. I. Kalygin, Early Bakhtin: Aesthetics as overcoming ethics (RGO Publishing house, Moscow, 2007). [in Rus.].

11. A. Gritten, Music in Bakhtin's Philosophical Aesthetics, Music Semiotics: A Network of Significations, Honour and Memory of Raymond Monelle (Ashgate Publishing, Ltd, 2012).

12. S. Fast, Bakhtin and the discourse of late medieval music theory, Plainsong \& Medieval Music, 5, 2, 175-191 (1996).

13. T. N. Levaya, M. M. Bakhtin and D. D. Shostakovich (some parallels), Dialogue. Carnival. Chronotope, 3-4, 17-27 (2000). [in Rus.].

14. Chronicle of F. I. Chaliapin's life and work, 2 (Music Publishing house, Leningrad, 1983). [in Rus.].

15. History of the Nevelsky District. Library Portal of the Pskov Region. Retrieved on 11 March 2019 from http://portal.pskovlib.ru/139-nevelskiy-rayon/kraevedenie]. [in Rus.].

16. A. I. Nemirovskij, V. I. Ukolova, The light of stars, or The last Russian Rosicrucian, (Progress, Culture Publishing house, Moscow, 1994). [in Rus.].

17. L. M. Maksimovskaya (ed.), Newspaper "Hammer" (1918-1920), Nevel Symposium, 1, 147-158 (AKROPOL Publishing house, St. Petersburg, 1996). [in Rus.].

18. A. F. Losev, The Woman Thinker, Moscow, 4, 98-119 (1993). [in Rus.].

19. M. V. Yudina, You'll be saved with music (Classic Publishing house, Moscow, 2005). [in Rus.].

20. I. I. Sollertinskij, Selected articles on music (Art Publishing house, MoscowLeningrad, 1946). [in Rus.].

21. M. F. Andreeva \& A. F. Mozhanskaya, Memories of Maria Veniaminovna Yudina (History of relations with two St.Petersburg families), Maria Yudina. Rays of Divine Love. Literary heritage, 642-657 (University book Publishing house, Moscow; St. Petersburg, 1999). [in Rus.].

22. V. M. Khodasevich, So I knew Gorky, New World, 3, 11-66 (1968). [in Rus.].

23. A. I. Tvetaeva, Inexhaustible (Fatherland Publishing house, Moscow, 1992). [in Rus.].

24. B. S. Uritzkaya, Remembering the past, Dialogue. Carnival. Chronotope, 1, 153-158 (1999). [in Rus.].

25. V. Barmichev \& V. Barmicheva, Memories of M. M. Bakhtin, Philologists as readers: Proceedings of the Intern. scientific conf., 173-184 (M. Batasova's Publishing House, Tver, 2011). [in Rus.].

26. M. Bakhtin \& L. Vasilyev, “At the daybreak", The Soviet Mordovia (1959). [in Rus.]. 
27. A. M. Kuznetzov, M. M. Bakhtin, October 11, 1973, from 5 to $7 \mathrm{pm}$, Dialogue. Carnival. Chronotope, 1-2, 288-305 (2003). [in Rus.]. 